\title{
Extraintestinal Involvements of Crohn's Disease Complicated with Nocardia Bacterium: An Overview Due to A Case
}

\author{
Onur Özgenç ${ }^{1 *}$, Seher Ayten Coşkuner ${ }^{2}$, Hakan Evren ${ }^{3}$, Meltem Avci ${ }^{2}$ \\ ${ }^{1}$ Dokuz Eylul University Vocational School of Health, Izmir, Turkey \\ ${ }^{2}$ Department of Infectious Diseases and Clinical Microbiology, Izmir Bozyaka Teaching and Research Hospital, Izmir, Turkey \\ ${ }^{3}$ Department of Infectious Diseases, Manavgat Ozel Bilgi Hastanesi, Antalya, Turkey
}

Received: February 22, 2017; Accepted: March 15, 2017; Published: March 20, 2017

*Corresponding author: Onur Özgenç, Dokuz Eylul University Hospital, Mesleksel Beceriler, Inciralti, Mithatpasa Cad No 1606, 35340, Balcova, Izmir, Turkey, Tel:+90-532-4153169; Fax:+90 232 4129798; E-mail:ozgenc.onur@gmail.com

\begin{abstract}
In this case report authors wanted to draw attention, to extraintestinal disorders of Crohn's disease; an old disease known for more than a century, and to an emerging infectious pathogen Nocardia; a recently emphasized challanging species. A case of Crohn's disease with complicated skin disorders, and acute compartment syndrome and cervical epidural abscess evolving due to Nocardia bacterium, has been discussed.

The two medical entities, the Crohn's disease with its extraintestinal involvements and nocardial infection with potential risk to cause disseminated infection especially in the immune compromised host, are the main subjects of this manuscript.

In this respect, it is concluded that the patients with Crohn's disease should be monitored closely for their extraintestinal involvements, and emerging and fastidious infections, so that the role of those infectious pathogens in the etiology of Crohn's disease can be further investigated.
\end{abstract}

Keywords: Crohn's disease; Pyoderma gangrenosum, Nocardia infection; Acute compartment syndrome, Epidural abscess

\section{Introduction}

Inflammatory bowel diseases fall into the class of autoimmune diseases, in which the body's own immune system attacks elements of the digestive system. Crohn's disease is one of the principal type of inflammatory bowel disease that may affect any part of the gastrointestinal tract. Signs and symptoms often include abdominal pain, diarrhea, fever, and weight loss. Crohn's disease may also involve the skin, joints, eyes, blood, liver, kidney, and endocrine system. The skin rashes may be due to infections as well as due to Pyoderma Gangrenosum (PG) or erythema nodosum. Although the etiological factors causing these symptoms of Crohn's disease are not well known, it is suggested that genetic predisposition may play a role, or bacteria or viruses may trigger the disease symptoms $[1,2,3]$.

Nocardia is an environmental bacterium found in water, decaying plants, and soil. In an immune compromised host this bacterium, being an opportunistic pathogen, can cause severe and progressive nocardial infections $[4,5]$. This aerobic filamentous bacterium is gram-positive and acid-fast with modified Kinyoun stain $[4,6]$. When aerial hyphae forming colonies on solid medias are detected not shorter than few days of incubation, the clinical microbiologist should judge on clinical and laboratory basis whether the bacteria are colonizing or infecting agents [7]. Therefore, in the absence of suspicion, the identification of Nocardia bacteria could be missed by the clinician, because the diagnoses of nocardial infections with conventional techniques have limitations [8].

\section{Case Report}

\section{First admission}

A 58-years old female referred to infectious disease clinic of a teaching and research hospital with high fever, abdominal pain, bloody diarrhea, and ulcerated lesion on the left forearm $(12 \times 5 \mathrm{~cm})$. The next day, wound developed depth and forearm swelled with severe pain and paresthesia. A diagnosis of Acute Compartment Syndrome (ACS) was made by the physical examination of a consulting orthopedic surgeon. With a rapid decision, she was taken into the operating room, and fasciotomy and deep surgical debridement of the lesion on her forearm were performed. After few days, her clinical status became more stable and she was undergone colon-sigmoidoscopy. The histopathological report confirmed Crohn's disease with superposing signs of pseudomembranous colitis (Table 1). Neither she nor her relatives gave suspicious medical history of inflammatory bowel disease.

On admission the Erythrocyte Sedimentation Rate (EST) was $58 \mathrm{~mm} / \mathrm{h}$. Blood results showed leukocytosis $\left(14600 \mathrm{~mm}^{3}\right)$, predominantly neutrophils, elevated $C$ reactive protein $(45 \mathrm{mg} /$ $\mathrm{dL}$ ), and anemia. Except moderate hypoproteinemia and minimum elevation of creatinine phosphokinase, all biochemical tests were within normal ranges. The direct stained specimens obtained for bacteriological culture revealed Gram-positive beaded small rods 
and coccoid fragments within leukocytes. Ziehl-Neelsen stained preparations were negative. The bacterium from pus material grew on blood agar as small chalky white colonies with musty odor, and also grew on Loewenstein-Jenseen medium and on corn meal agar as a pure culture within one week. The filamentous branching rods were seen with Ziehl-Neelsen with $1 \%$ sulphuric acid (modified Kinyoun technique) stained preparations, a typical feature of nocardiae (Table 2). The cultures were kept incubated for 3 more weeks. With the formation of aerial hyphae the bacterium was identified as Nocardia spp. $[4,9]$. The strain was reported as sensitive to cefotaxime, ceftriaxone, cefepime, imipenem, meropenem, vancomycin, teicoplanin, erythromycin, clarithromycin, rifampicin, minocycline, doxycycline, linezolid,

Table 1: Schematic summary of the clinical observations and the implemented therapy of the Crohn's disease and the nocardial infection.

\begin{tabular}{|c|c|c|}
\hline $\begin{array}{l}\text { Symptoms and } \\
\text { Findings }\end{array}$ & Diagnosis & Primary therapy \\
\hline \multicolumn{3}{|l|}{ First admission } \\
\hline \multicolumn{3}{|l|}{ High fever } \\
\hline $\begin{array}{l}\text { Abdominal pain, } \\
\text { Bloody diarrhea }\end{array}$ & $\begin{array}{l}\text { Crohn's disease and } \\
\text { pseudomembranous } \\
\text { colitis }\end{array}$ & $\begin{array}{l}\text { IV* fluid replacement } \\
\text { therapy }\end{array}$ \\
\hline $\begin{array}{c}\text { Ulcerated lesion on } \\
\text { the left forearm }\end{array}$ & $\begin{array}{l}\text { ACS }^{* *} \text { and Nocardial } \\
\text { infection } \\
\text { (bacteriological culture } \\
\text { positive) }\end{array}$ & $\begin{array}{c}\text { Fasciotomy and } \\
\text { debridement } \\
\text { Ceftriaxone, vancomycin, } \\
\text { doxycycline }\end{array}$ \\
\hline \multicolumn{3}{|l|}{$\begin{array}{c}\text { Second } \\
\text { admission }\end{array}$} \\
\hline \multicolumn{3}{|l|}{ High fever } \\
\hline $\begin{array}{l}\text { Abdominal pain, } \\
\text { Bloody diarrhea }\end{array}$ & Crohn's disease & $\begin{array}{l}\text { IV fluid replacement } \\
\text { therapy }\end{array}$ \\
\hline $\begin{array}{l}\text { Pain and } \\
\text { inflammation on } \\
\text { the right dorsal } \\
\text { foot and ankle }\end{array}$ & $\mathrm{PG}^{* * *}$ & $\begin{array}{l}\text { Ceftriaxone } \\
\text { Prednisolone }\end{array}$ \\
\hline $\begin{array}{l}\text { Limitation on neck } \\
\text { movements }\end{array}$ & $\begin{array}{c}\text { Nocardial cervical } \\
\text { epidural abscess } \\
\text { (culture not available) }\end{array}$ & $\begin{array}{c}\text { Meropenem, vancomycin, } \\
\text { linezolid }\end{array}$ \\
\hline \multicolumn{3}{|c|}{$\begin{array}{l}\text { *IV; Intravenous } \\
\text { **ACS; Acute Compartment Syndrome } \\
\text { ***PG; Pyoderma Gangrenosum }\end{array}$} \\
\hline
\end{tabular}

Table 2: The identification process of Nocardia bacterium from the wound specimen of the left forearm.

\begin{tabular}{|c|c|c|c|}
\hline \multicolumn{2}{|c|}{ Microscopy } & \multicolumn{2}{|c|}{ Bacteriological culture } \\
\hline Direct & $\begin{array}{c}\text { Small rods } \\
\text { and coccoid } \\
\text { fragments within } \\
\text { leukocytes }\end{array}$ & \multirow{2}{*}{$\begin{array}{c}\text { Within } 1 \text {-week of } \\
\text { incubation }\end{array}$} & \multirow{2}{*}{$\begin{array}{l}\text { Small chalky } \\
\text { white colonies } \\
\text { with musty } \\
\text { odor }\end{array}$} \\
\hline Gram staining & $\begin{array}{l}\text { Gram-positive, } \\
\text { beaded, } \\
\text { filamentous } \\
\text { branching rods }\end{array}$ & & \\
\hline $\begin{array}{l}\text { Acid-fast staining: } \\
\text { 1) Ziehl-Neelsen } \\
\text { 2) Kinyoun }\end{array}$ & $\begin{array}{l}\text { Negative } \\
\text { Positive }\end{array}$ & $\begin{array}{c}\text { Within 3-weeks } \\
\text { of incubation }\end{array}$ & $\begin{array}{c}\text { Aerial hyphae } \\
\text { formation }\end{array}$ \\
\hline
\end{tabular}

and resistant to trimethoprim/sulphamethoxazole (TMP/SXT), amikacin, tobramycin, ciprofloxacin, and levofloxacin with standard disk-diffusion susceptibility testing.

The patient was on treatment with ampicillin-sulbactam. Then following bowel biopsy report and information obtained from clinical microbiology laboratory the treatment was switched to ceftriaxone and vancomycin combination. The response to this regimen was good. The colitis resolved and the wound started healing. Within one month of systemic and topical wound therapy, the open wound on forearm was nearly closed. Upon discharge from the hospital, the maintenance therapy with doxycycline and teicoplanin was prescribed for two more weeks. She was advised to come for follow-ups.

\section{Second admission}

After two years, the patient (who did not show up for control examinations) presented again with the complaints of abdominal pain and bloody diarrhea. She told that she went to local doctors and she was under antibiotics therapy for her diarrhea. She was followed for two days with mild gastrointestinal discomfort and on the third day she had high fever, and pain and inflammation on her right dorsal foot and ankle $(13 \times 6 \mathrm{~cm})$. On examination she also had some limitations on her neck movements, and appearance of scar on her left forearm due to healing of her previous wound. With these findings soft tissue ultrasonography for right foot and cervical magnetic resonance imaging were planned. The inflammation on right dorsal foot showed worsening within one day, spontaneous pus drainage started. The gastroenterologist and dermatologist visiting the patient diagnosed the lesion as Pyoderma Gangrenosum (PG), complication of Crohn's disease. In addition to ceftriaxone regimen, prednisolone $1 \mathrm{mg} / \mathrm{kg}$ was started. The orthopedic surgeon followed the wound for topical treatment and prognosis, and bone involvement was not observed on x-ray examination. On Magnetic Resonance Imaging (MRI) of the cervical vertebras on C5-6 and T1-2 levels, epidural collection $(51 \times 11 \mathrm{~mm})$ was reported. The antibiotics implemented were meropenem, vancomycin, and linezolid. The bacteriological blood and pus specimens from wound did not reveal any growth. The leukocytosis and high CRP detections at the beginning of the symptoms returned to normal levels after 4 weeks. The wound defined as PG improved totally within 45 days. There was no abscess formation on the repeated MRI of the cervical vertebral column after two months, and the physician reported complete regression of her cervical neck stiffness. The patient who was in well being was discharged from the hospital with doxycycline, clarithromycin, and teicoplanin maintenance therapy for two additional weeks, which the Nocardia bacterium isolated at the first hospital admission was susceptible to all antibiotics in the regimen. She was followed up regularly for six more months with no complaints.

\section{Discussion}

Crohn's disease may involve any part of the digestive system, and commonly affects the terminal ileum and colon $[1,3,10]$. The inflammation of the intestine usually appears before the age of 30 . Only the small proportion of people may develop the 
disease between the ages of 50 through 70 . Although the cause is unknown there are some evidences that the disease could be triggered by a microorganism on hereditary basis $[1,3]$.

The 58-years old patient had severe onset of inflammatory bowel disease without medical history of frequent diarrhea in the past, and neither the relatives developed the disease. On first admission to the hospital the patient had pseudomembranous colitis with underlying Crohn's disease. She also had ACS evolving on nocardial soft tissue infection. It is known that there is predisposition to pseudomembranous colitis in patients with inflammatory bowel diseases [11]. At that point authors could discuss that the symptoms of pseudomembranous colitis were due to severe Crohn's disease or those symptoms were triggered by the bacterium $[1,2]$. If bacterium was the cause, since crohn is an inflammatory disease, could it be Nocardia? For the exact answer the investigators had to grow Nocardia bacteria in large quantities in the stool. Since no stool culture for that fastidious microorganism was taken into consideration; to attribute the cause of pseudomembranous colitis to Nocardia bacteria could only be commentary. Meanwhile, a fulminant nocardial colitis case, reported in a woman patient with past history of Crohn's disease [12], seemed to support the authors' hypothesis.

Acute compartment syndrome is a rare complication usually following trauma, circulation disorders, burns, or sometimes invasive infections [13], which requires immediate surgery [14]. It develops as a result of increased interstitial tissue pressure in a closed anatomic compartment, so surgical decompression is needed [15]. Although urgent fasciotomy is indicated, in the presence of infection it is controversial [16]. So, in addition to fasciotomy deep surgical debridement is necessary. Here in, the nocardial skin infection was complication of Crohn's disease which is an autoimmune disorder. In PubMed/MEDLINE search of nocardial infections in patients with Crohn's disease, although infrequent, there are few reported cases $[17,18]$, and this is the only described case of ACS in relation to nocardial infection. In the present case the bacterium is isolated from the cutaneous infection with suspicion of the authors, who are clinical microbiologists with previous experience with Nocardia bacteria $[19,20]$.

On patient's second admission to the hospital the remarking clinical finding was PG. Pyoderma gangrenosum is rapidly developing ulcerative, necrotic, and painful dermatosis with surrounding erythema. The etiology of this sterile, neutrophilic process is unknown [21]. Sometimes it mimics necrotizing fasciitis [22]. Very rarely PG and necrotizing fasciitis-like opportunistic fungal infections are observed within skin biopsy specimens of the same host [23]. Our patient's wound presumed to be sterile but the patient was under pressure of antibiotics. Meanwhile, a good therapeutic response was achieved with antibiotics regimen along with prednisolone.

The most serious finding of the patient was epidural abscess formation diagnosed early in the course with the onset. Although the etiological agent could not be isolated because of the high dose of antibiotic implementation, the medical history of the case lead the authors to nocardial Central Nervous System (CNS) infection. Nocardiaosis of the CNS, although is seen infrequently is a life-threatening disease in patients with weak immune systems; in those the fatality rate is more than $85 \%$ [5]. To best of our knowledge, there is only one reported Crohn's disease case with cerebral nocardiosis [24]. With early antibiotic combination the patient's epidural abscesses within the cervical location of the spinal column was treated successfully, otherwise, the patient might have needed neurosurgical emergency.

All infrequent disorders coincidentally met in one Crohn's disease case is discussed. The extraintestinal disorders of the disease in conjunction with Nocardia bacterium is evaluated. Although not fully documented, the relationship of Mycobacterium avium subspecies paratuberculosis (MAP) with Crohn's disease is underlined by many investigators $[2,3,10,25]$. It is debated that anti-MAP antibiotics can play role as a therapeutic agent in the course of the inflammatory colitis [3]. The MAP from Mycobacteriaceae and Nocardia species from Nocardiacea families are both in aerobic actinomycetes group [9]. Further studies on molecular basis are needed to designate the role of these infectious pathogens in the etiology of Crohn's disease.

The authors conclude that the patients with Crohn's disease should be monitored closely for their extraintestinal involvements, and emerging and fastidious infections.

\section{References}

1. Mayo Clinic Staff. Diseases and Conditions Crohn's disease. [cited 2014 Aug 14].

2. Centers for Disease Control and Prevention (CDC). Paratuberculosis Awareness and Research Association, 1999-2003.

3. Centre for Digestive Diseases (CDD). Crohn's disease. [cited 2009].

4. Bell M, McNeil MM, Brown JM.Nocardia species (Nocardiosis). In: Yu VL, Weber R, Raoult D, Edwards G, McKinnon PS, Pelquin CA, Morse GD, Burdette SD, editors.Antimicrobe; Infectious disease and antimicrobial agents.

5. Centers for Disease Control and Prevention (CDC 24/7). Nocardiosis. [cited 2016 March 30].

6. Wilson JW. Nocardiosis : Updates and clinical overview. MayoClin Proc. 2012;87(4):403-407. Doi:10.1016/j.mayocp.2011.11.016

7. Brown-Elliott BA, Brown JM, Conville PS, Wallace RJ. Clinical and laboratory features of the Nocardia spp. based on current molecular taxonomy. Clin Micro Rev. 2006;19(2):259-282. Doi:10.1128/ CMR.19.2.259-282.2006

8. Atzori L, Pinna AL, Pau M. Cutaneous Nocardiosis. SOJ Microbiol Infect Dis. 2014;2(1):8. Doi:10.15226/sojmid.2013.00110

9. Sorrell TC, Mitchell DH, Iredell JR, Chen SC-A.Nocardia species. In: Bennett JE, Dolin R, Blaser MJ, editors. Mandell, Douglas, and Bennett's principles and practice of infectious diseases. 8th ed.Philadelphia: Elsevier Saunders; 2014. p. 2853-2863.

10. Hermon-Taylor J, Bull T. Crohn's disease caused by Mycobacterium avium subspecies paratuberculosis: a public health tragedy whose resolution is long overdue. J Med Microbiol. 2002;51(1):3-6.

11. Mayo Clinic Staff. Pseudomembranous colitis. [cited 2016 Jan 8] 
12. Turer D, Gray B, Raghavendran K. Fulminan Nocardia colitis: A case report. Surg Infect Case Reports. 2016;1(1):69-71. doi:10.1089/ crsi.2016.0013

13. Kleshinski J, Bittar S, Duggan JM, Wahlquis MC, Ebraheim N. Review of compartment syndrome due to group A streptococcal infection. Am J Med Sci. 2008;336(3):265-269. doi:10.1097/MAJ.0b013e318165650a

14. Stracciolini A, Hammerberg EM. Acute compartment syndrome of the extremities. In: Moreira ME, Bachur RG, editors. UpToDate. [cited 2016 May 13].

15. Chandraprakasam T, Ashok Kumar R. Acute compartment syndrome of forearm and hand. Indian J Plast Surg. 2011;44(2):212-218. doi:10.4103/0970-0358.85342

16. Wood J, Walsh JJ, Genova R. Fasciotomy. In: DeBerardino TM, editor. Medscape [cited 2015 Sep 28].

17. Saleemuddin A, Govender PP, Farraye FA. Nocardia pneumonia in a patient with Crohn's disease receiving 6-mercaptopurine and infliximab. J Crohns Colitis. 2014;8(7):708-709. doi:10.1016/j. crohns.201311.023

18. Singh SM, Rau NV, Cohen LB, Harris H. Cutaneous nocardiosis complicating management of Crohn's disease with infliximab and prednisone. CMAJ. 2004;171(9):1063-1064. doi:10.1503/ cmaj.1040563
19. Özgenç O, Avcı M, Arı A, Celebi IY, Coşkuner SA. Long-term treatment of persistent disseminated Nocardia cyriacigeorgica infection. Braz J Infect Dis. 2014;18(5):556-560. doi:10.1016/j.bjid.2014.03.007

20. Ozan F, Koyuncu Ş, Kızılay C, Özgenç O. The Nocardia farcinica infection developing after total knee arthroplasty. Surgery Acta Orthop Traumatol Turc. 2013;47(3):212-217.

21. Riyaz N, Mary V, Sasidharanpillai S, Roshin RA, Snigdha O, Latheef EN, et al. Pyoderma gangrenosum: A clinico-epidemiological study. Indian J Dermatol Venereol Leprol. 2017;83(1):33-39. doi:10.4103/03786323.188654

22. Včelák J, Šuman R, Beneš J. Pyoderma Gangrenosum Mimicking Necrotising Fasciitis after Rotator Cuff Reconstruction . Acta Chir Orthop Traumatol Cech. 2016;83(2):127-130.

23. Aytekin S, Güder H, Göktay F, Yaşar Ş, Aker F, Aksaray S. Pyoderma gangrenosum and necrotizing fasciitis-like opportunistic invasive cutaneous fungal infection. Inter J Dermatol. 2016;55(10):e563-e565. doi:10.1111/ijd.13296

24. Khalesi N, Taghipour R, Aflatoonian M. A case report of cerebral nocardiosis in a patient with Crohn's disease Razi J Med Sci. 2010;16(67):40-63.

25. Rosenfeld G, Bressler B. Mycobacterium aviumparatuberculosis and the etiology of Crohn's disease: A review of controversy from the clinician's perspective. Can J Gastroenterol. 2010;24(10):619-624. 